\title{
Recombinant human erythropoietin in sports: a review
}

\author{
Rafael Maia de Almeida Bento ${ }^{1}$, Lúcia Menezes Pinto Damasceno ${ }^{1}$ \\ and Francisco Radler de Aquino Neto ${ }^{1}$
}

\begin{abstract}
Erythropoietin is an endogenous hormone of glicoproteic nature secreted by the kidneys and is the main regulator of the erythropoiesis. An alteration in its production generates a disturbance in the plasmatic concentration giving rise to several types of pathologies related to the hematopoietic system. The recombinant forms of erythropoietin have indiscriminately been used by athletes, mainly in endurance sports, by increasing the erythrocytes concentration, generating a better delivery of oxygen to the muscle tissue. The administration of recombinant erythropoietin was prohibited by the International Olympic Committee and its use considered as doping. This review has the intention to describe the physical, biological and pharmacokinetic properties of the endogenous erythropoietin, as well as its recombinant form, describing also its use in sports and the process of searching methodologies for its detection in doping control.
\end{abstract}

Key words: Erythropoietin. Epoetin. Peptidic hormones. Doping control.

\section{INTRODUCTION}

Erythropoietin (EPO) is an endogenous hormone of glicoproteic nature synthesized particularly in specific epithelial cells that line renal peritubular capillaries ${ }^{1}$. This hormone is the main regulator of erythropoiesis in man and other animals. The kidneys play a major role in its synthe-

1. Laboratório de Controle de Dopagem (LAB DOP-Ladetec) do Instituto de Química da Universidade Federal do Rio de Janeiro (UFRJ), Rio de Janeiro, RJ, Brasil.

Received in 31/1/03

$2^{\text {nd }}$ version received in 25/4/03

Accepted in 17/5/03

Correspondance address:

Lúcia Menezes Pinto Damasceno

Centro de Tecnologia, Instituto de Química

Bloco A, sala 512, Cidade Universitária - Ilha do Fundão

21949-900 - Rio de Janeiro, RJ

E-mail: lucia@iq.ufrj.br sis, as they secrete about $90 \%$ of all systemic EPO. The liver makes about $10 \%$ of all $\mathrm{EPO}^{1,2}$.

Due to its inherent ability to stimulate red cell production, and thus increase oxygen delivery to the tissues, the use of EPO was banned in sports by the International Olympic Committee (IOC) in $1987^{3}$. Depending on the sports modality, EPO administration to elite athletes may lead to an artificial performance improvement, decreasing, for instance, their time marks. In order to maintain health of the individual and sports ethics, IOC and other sports federations currently consider the use of EPO and its analogue drugs as blood doping cases due to exogenous administration of peptide hormone ${ }^{4}$.

Availability of this class of compounds in the market dramatically increased in the $80 \mathrm{~s}$, with the advent of recombinant DNA technology 5 . EPO synthetic form, recombinant human EPO (rHuEPO), started to be marketed in $1988^{3}$; since then, it has been successfully used in medical care, improving quality of life of patients in constant need of blood transfusions, or with anemia due to chronic renal failure ${ }^{2,5}$. In sports, at the same time, one speculates that rHuEPO was routinely used as an artificial way to produce red cells $s^{6}$, due to the extra advantage of its presence in the biologic matrix being hard to be detected by conventional analytic methods, in addition to an effective sports performance gain. Difficulties in detection are due to the fact that EPO is a complex macromolecule, present in low concentrations in biologic fluids, with quite a similar structure to its endogenous form, which made impossible for one to accurately identify its illicit use for a long time ${ }^{7,8}$.

The purpose of this review is to place the current scientific stage in fighting EPO abuse in sports. After a short summary of endogenous EPO chemical and pharmacological properties and its recombinant forms, report of suspicious cases of EPO abuse in sports will be presented. Then, the evolution of the analytical methodology to identify and differentiate physiological EPO and its synthetic recombinant form, to apply it in doping control in sports, will present. Also new trends in the development of detection technique, and the potential use of new EPO analogue drugs available in the market will be discussed. 


\section{ENDOGENOUS ERYTHROPOIETIN}

Human EPO is synthesized in the kidney cell, initially as a pro-hormone comprised of a total sequence of 139 amino acids, being the first 27 for hormone secretion only, but with no role in biologic activity ${ }^{5,9}$. Shortly before secretion, EPO is cleaved, and these 27 amino acids are taken away. Upon entering the blood stream, amino acid arginine in the carboxi-terminal position is lost, thus leaving the hormone with a final sequence of 165 amino acids, aligned in a single polypeptide chain, with two intramolecular disulfate bindings and four independent polysaccharide chains bound to specific amino acid residues. The polysaccharide chains comprise about $40 \%$ of EPO's molecular mass, and are highly important in hormonal function. In order to prevent swift EPO depuration in the liver before it reaches its physiological target, the macromolecule has a biologic marker comprised of sialic acid and residues located in strategic positions of the polysaccharide chain ${ }^{3}$. EPO's halflife after entering the blood stream is estimated in 6 to 8 hours ${ }^{1}$.

EPO production by renal specialized cells and its further entrance in the blood stream take place when renal sensitive cell structures perceive a decrease in the circulating oxygen or a deficiency in the production of erythrocytes, leading to a decrease in circulating erythrocytes ${ }^{10,11}$. The produced EPO molecules that enter the blood stream are carried to the bone marrow, where they find erythrocyte mother cells. One sees the increase in the rate of new circulating erythrocytes produced by the bone marrow within 1 to 2 days after EPO plasma levels increase ${ }^{10,12}$. Due to the short interval of time between peak serum EPO and the increase in concentration of new erythrocytes, one concludes that EPO acts on precursory cells close to maturated erythrocytes, rather than on more primitive cells or erythrocyte genesis ${ }^{10}$. These precursory cells are called erythrocytecolony forming cells (CFC-E), and their marked feature is responding to EPO only. Such cells have specific receptors that belong to a broad family of receptors for hematopoietic growth, and they manage to respond to very low concentrations of this hormone, of $10^{-12} \mathrm{~mol} / \mathrm{L}^{10}$. Upon binding to its receptor, EPO causes a dimerization on the extra cellular surface of the former, triggering autophosphorylation and intracellular activation of proteins tyrosine and kinase $^{13}$. The hormonal stimulus keeps on until oxygen level in tissue goes back to normal values. The EPO receptor is also present in non-erythroid tissues, such as endothelial and brain cells. The role of this receptor in these sites is still not well understood, but mutations in its structure may be associated to some diseases in these tissues ${ }^{14}$.

The EPO-activated CFC-Es generate mature erythrocytes after six cell-splitting cycles. At this stage, the CFC-Es do not contain hemoglobin, the protein responsible for transporting oxygen and the highest-volume component of the maturated erythrocyte. The produced CFC-Es depend only from the EPO to survive and proliferate. In vitro studies show that removing EPO from a CFC-E culture leads to a rapid process of programmed cell death, called apopto$\operatorname{sis}^{1,10,15}$.

The erythrocytes produced during erythropoiesis do not have genetic material nor cellular capability for replication, as both cytoplasm nucleus and major organelles, such as endoplasmic reticulum, mitochondria and ribosomes are extruded from the cell, to allow for more hemoglobin to be stored $^{5,10}$. Therefore, the only means for erythrocyte production is through hormone stimulation of CFC-E cells from pluripotent hematopoietic stem cells ${ }^{10}$.

For having this vital role of erythropoiesis regulation, any factor or disturbance affecting the concentration of serum EPO, either in its synthesis or release to the blood stream, will lead to a variable deregulation in the homeostasis of the hematopoietic system. The serum EPO concentration changes as consequence of shifts in the oxygen availability in the kidney. Hemodilution, the different types of hypoxia and the different forms of anemia are known causes for increase in EPO production and concentration. Conversely, EPO concentration is reduced in polycythemia ${ }^{2}$. Furthermore, patients with some kidney conditions whose body is unable to produce EPO may present anemia, due to a decreased concentration of this hormone ${ }^{5}$. Maximum or sub-maximum exercises do not have immediate effects on EPO concentration, whereas overexertion of physical activities may cause changes in hormone concentration. This concentration may present variations in a same individual or among individual during the day, and in different physiological situations, which makes harder to detect an abusive use of rHuEPO in sports, for instance ${ }^{2}$.

\section{RECOMBINANT HUMAN ERYTHROPOIETIN}

\section{rHuEPO synthesis}

The production of EPO in commercial amounts and of high degree of purity was made possible thanks to genetic engineering techniques, which allowed the development of a correlated recombinant chemical ${ }^{16}$.

The initial milestone for the genetic production of EPO was a highly purified preparation of the protein, which was achieved by isolating and purifying the hormone from 2,550 liters of aplastic anemia patients' urine, in the end of the 70s. At this time, endogenous EPO was identified as a glucoprotein with molecular weight of approximately 34,000 daltons, and hormonal activity of 70,000 UI/ $\mathrm{mg}^{17}$. However, EPO production on an industrial scale from the purifica- 
tion of the human endogenous form for therapeutic use is not feasible, because this hormone is present in the human body in very low concentrations ${ }^{16}$.

The steps that made feasible and triggered a new era in the manufacturing of synthetic EPO were the isolation and characterization of the human DNA region that codifies endogenous EPO, and the creation of a complementary mold copy of the same region (cDNA). Isolation and characterization of the DNA region were achieved by obtaining the sequencing of physiologic EPO's amino acids, following a path reverse from its protein synthesis. This sequencing, obtained from modern chemical and genetic technique later on led to the mapping of the protein-codifying DNA nitrogenous bases sequencing. Once the complete sequence was at hand, it was compared to other nitrogenous bases sequences from DNA gene bank, to determine the right position in which the sequence was found in the human genoma $^{18}$. At the same time, the development of a DNA complementary mold copy was implemented. For this purpose, the messenger RNA (m-RNA) that codifies this protein was isolated from fetal liver cells, because of their highly production of native EPO. The CDNA generated by using reverse transcriptase enzyme created a complementary copy of m-RNA, i.e., the protein sequence in the DNA. Finally, CDNA was incorporated to bacterial plasmids, which were placed to a host $E$. coli bacterium. The bacterial strain, from this point onward, contained the full genetic information for EPO production. The rHuEPO was the first cloned hematopoietic growth factor ${ }^{18}$.

Since then, cDNA clones of physiologic EPO have been isolated in different labs, in order to obtain higher amounts of rHuEPO. The expression of EPO's cDNA clones may be also obtained from incorporating to the genetic material isolated cells from mammals, such as ovarian cells of Chinese hamster $(\mathrm{CHO})$, or kidney cells from hamster cub $(\mathrm{BHK})^{3}$. These type of cells are favored for rHuEPO production because the complex structure of the protein has biologically essential disulfate bindings and standards of glucolisation that can only be duplicated from their expression in cell cultures of mammals ${ }^{16}$. The rHuEPO thus produced is homogeneous as to the peptide sequence of natural EPO, but it is heterogeneous in the carbohydrate portion ${ }^{3}$. The rHuEPO was the first biomedication produced from heterologous cells of mammals ${ }^{19}$.

Currently, rHuEPO has been produced by different manufacturers, and in spite of its biologic activity being equal to the one of its native form, the two- and three-dimension chemical structures of manufactures rHuEPO not always present full analogies, either when compared among themselves or to natural EPO. Because they come from different sources of synthesis, from different parts of the world, vari- ations in the composition and disposition of the polysaccharide structure of each product are particularly observed ${ }^{5}$. Studies with EPO molecules from different exogenous origins show that, like those of many glucoprotein hormones in physiologic $\mathrm{pH}$, its structure has an heterogeneous load due to minor content variations of the polysaccharide portion $^{20}$. The rise of a black market for rHuEPO over the past years has underlined such differences, due to variability and unsteady quality of the ingredients of each marketed product ${ }^{5}$.

\section{rHuEPO therapeutic use and route of administration}

In addition to its primary use as a convenient medication for patients who need successive blood transfusions or present anemia from chronic renal failure ${ }^{2,5}$, rHuEPO has lately been used also for other types of anemia, such as the one from early stage of cancer ${ }^{16}$, or from the use of AZT in HIV-positive patients, among others ${ }^{3}$.

The usual rHuEPO dosage for the treatment of anemia typically ranges from 20 to $240 \mathrm{UI} / \mathrm{Kg}$ three times a week, depending of patient response and optimum rate of hemoglobin plasma concentration, and hematocrit ${ }^{5,19,21}$. In the medical practice, intravenous, subcutaneous and intraperitoneal are the most common rHuEPO route of administration $^{19,22}$. Selection of the route will depend on pharmacokinetic considerations and practicability. In patients undergoing hemodialysis, rHuEPO may be administered intravenous or at the end of the procedure, thus reducing patient suffering. For patients in conservative treatment of kidney failure, kidney transplanted patients or patients under peritoneal dialysis, one recommends subcutaneous administration of rHuEPO, alternating sites within thighs, to spare peripheral veins for future vascular access. Intraperitoneal administration should be left for special medical situation in patients undergoing peritoneal dialysis, particularly children who get upset with injections ${ }^{22}$. The low availability through this route requires a weekly dosage higher than for other routes of administration. One notices that erythropoiesis responds more effectively to frequent rHuEPO injections in fractionated dosages than to intermittent peaks from high dosages ${ }^{23}$. However, none of the modalities or routes of exogenous administration duplicates the physiologic secretion standard or the circadian rhythm of the natural hormone ${ }^{22}$.

After intravenous administration maximum serum rHuEPO concentration peaks are reached within minutes, whereas time to reach maximum peak values from subcutaneous administration may range from 5 to 24 hours after administration $^{24}$, or a little more ${ }^{22}$. Clinical trials carried out in mid 90s to assess intravenous and subcutaneous route of administration did not show differences in the effective- 
ness of treatment or in blood pressure when the two routes were compared. Subcutaneous administration is of low and variable bioavailability ${ }^{25}$, ranging from 20 to $40 \%{ }^{22}$, and yet it generates high serum levels of $\mathrm{rHuEPO}^{25}$. In spite of the fact that, about 30 years ago one believed that endogenous EPO urine concentration was approximately proportional to its serum level, and with a daily output rate of less than $10 \%$ of the total amount administered ${ }^{26}$, one knows today that rHuEPO urinary excretion after administration in healthy volunteers is negligible, less than $1 \%$ of the administered dose ${ }^{27}$. It was suggested, at that time, that liver and the marrow were possible depuration site of endogenous $\mathrm{EPO}^{26}$. It is known, today, from the presence of hepatic degradation products ${ }^{28}$, that the liver is actually involved in rHuEPO degradation process, after gradual removal of sialic acid end residues from the molecule (in vivo desialation), which is a limiting step for depuration rate of systemic $\mathrm{EPO}^{28,29}$.

\section{rHuEPO marketed forms}

Epoetin alpha, epoetin beta and epoetin omega are the commercial names for forms of rHuEPO currently available in the market for therapeutic use $\mathrm{e}^{30,31}$. This classification depends on the manufacturing method, the first two ones being synthesized from $\mathrm{CHO}$ cells, the later being produced from BHK cells. In spite of protein glucosilation by $\mathrm{CHO}$ and BHK cells being quite similar to the one made by human cell, some areas of carbohydrate cells are not synthesized by these cells, for lack of specific glucotransferase enzymes. While the synthesis of the peptide chain is genetically regulated, polysaccharide chains are processed and bound by a series of enzymatic reactions ${ }^{30}$.

Comparisons made among different lots of epoetin alpha and epoetin beta have indicated different biologic activity between them, due to different values found for relative potency ratio in vivo : in vitro for each of these forms, being the values higher for the beta than for the alpha form ${ }^{31}$. These rHuEPO forms include different isoform types, due to micro-heterogeneity in the hormone structure from variations in the polysaccharide formation ${ }^{3,30,31}$. The rHuEPO isoforms alpha and beta partially differ in their composition when analyzed by isoelectric focalizing technique. Through this technique, it is possible to visualize not only a higher number of bands related to epoetin beta isoforms, meaning a higher amount of isoforms, and a region with extra bands of higher $\mathrm{pH}$, giving them more basic features ${ }^{31}$.

In addition to variations as to their biologic activity and structural composition, the two rHuEPO forms have different pharmacokinetic and pharmacodynamic profiles, being the distribution volume and excretion half-life of $7.7 \%$ and $20 \%$ respectively, higher for epoetin beta in relation to epoetin alfa ${ }^{32,33}$. However, the clearance for both is not significantly different ${ }^{32}$, which goes against results of prior studies $^{34,35}$.

As to subcutaneous administration, there is a delay in epoetin beta absorption when compared to epoetin alpha, with lower values for epoetin beta serum concentration over the first 18 hours after administration. However, from 48 to 66 hours after administration, epoetin beta serum concentration values surpass the ones for epoetin alfa $^{32}$. Values of maximum EPO serum concentration $\left(\mathrm{C}_{\max }\right)$, time for $\mathrm{C}_{\max }\left(\mathrm{t}_{\max }\right)$, and area under the curve (AUC) are not significantly different between the forms, showing similar bioavailability ${ }^{32,33}$.

It is interesting to note the report of volunteers as to feeling pain when using the alpha form $(56 \%)$, when compared to the beta form $(5,6 \%)$, after subcutaneous administration $^{32}$. Patients undergoing hemodialysis being treated with rHuEPO for anemia due to chronic renal failure have shown similar reactions in a subjective study using points to indicate the intensity of pain. It is suggested, as an explanation for such different behavior from the two forms, that the ingredients used in the formula of each medication, or the type of rHuEPO itself, would be responsible for differences in pain reaction ${ }^{36}$.

\section{USE OF rHUEPO IN SPORTS}

The definition of blood doping came about in the 70s, to describe the use of blood transfusions to artificially increase the mass of red cells, allowing a higher disposition in oxygen delivery, particularly in sports requiring resistance, where aerobic muscular exercise prevail, such as cycling, cross-country skiing ${ }^{37,38}$, long-distance race, marathon ${ }^{8}$, and triatlon $^{38}$, among others. Aerobic exercise is an expression associated to performing intense exercise for an extended period of time. The ability to perform an aerobic workout is closely related to the amount of oxygen that may be transported to the muscles ${ }^{39}$.

Blood doping ${ }^{21,40-42}$ was formally added to the list of forbidden methods in 1985, after many United States cyclists admitted having doped themselves with blood during the 1984 Los Angeles Olympic Games ${ }^{43}$. However, over time, legal, ethical and religious issues have hampered blood sampling, as blood collection is an invasive method ${ }^{21,42,44}$. Nonetheless, regular tests using blood have been performed in athletic competitions in 1993 and 1994. At that time, attention was focused to tracking doping from blood transfusion, in detecting some forbidden endogenous steroids and peptide hormones. For the later, however, the assays were of very low sensitivity, and done with the use of immunologic techniques ${ }^{40}$. 
Currently, blood doping is more closely related to rHuEPO administration than to possible types of transfusion ${ }^{37}$. Transfusion has been gradually disfavored, due to the need for a doctor or other trained professionals to take out, prepare, store and do the blood transfusion. On the other hand, rHuEPO may be obtained and administered without medical supervision, which increase the risk of abusive use ${ }^{45-47}$.

Even before rHuEPO was marketed, one suspected the possibility of abusive use by athletes seeking to artificially enhance their performance, up to the point when rumors and anonymous accusations on its illicit use came out. In the years following rHuEPO sintesis, many news articles reported the use of peptide hormones, such as epoetin alpha, but there was no hard evidence of its manipulation ${ }^{6,43}$. The scientific community, however, knew that sooner or later this drug would be used, as it increases hemoglobin levels without the complications or difficulties presented by other types of blood doping.

To prevent the use of rHuEPO for sports performance enhancing, educational programs showing the risks of potential side effects were developed, showing that doses given to patients to increase their hematocrit could not be extended to healthy people ${ }^{6}$; furthermore, even after administration is suspended, the effect of the hormone on the bone marrow could still last for some more days, and the hematocrit could increase to hazardous levels ${ }^{47}$. Dehydration, very common after strenuous physical exercise in a sports competition, added to hemoconcentration, could place health under imminent risk, due to increase in blood thickness and decrease or cardiac output ${ }^{6,38,39,48,49}$, causing high blood pressure ${ }^{5,48,49}$ and possible thrombotic events $6,38,39,48,50$.

Even though rHuEPO use in therapeutics is somewhat safe when done under medical supervision, cases of erythrocytic aplasia in patients using rHuEPO have been reported, albeit its low incidence. The development of anti-EPO antibodies occurs, neutralizing both rHuEPO and its endogenous form, and triggering that medical condition ${ }^{51}$. However, a significant improvement of quality of life and/or extending survival associated to a reduced prevalence of disease in these patients make up for the risk of prescribing this drug for therapeutic purposes. However, rHuEPO doping by healthy athletes who do not need any treatment is not acceptable, and the risk of developing disease is potential, and may lead to dependence of continuing blood transfusions for the rest of their lives ${ }^{52}$.

Fatal cases connected to doping occurred in early 90s, when professional Dutch cyclists competing in Europe died at rest, some of them while sleeping, due to unexplainable cardiac arrest ${ }^{5,37,39}$. These sportsmen are among the more than 20 cases of death of cyclists in Europe reported be- tween 1987 and 1991, when rHuEPO was first made available in that continent $\mathrm{t}^{46,53,54}$.

Evidences on the use of rHuEPO were found after a blood check of Italian professional cyclists that showed serum iron overload comparable to those of genetic hemochromatose patients. The levels of ferritin (a protein associated to the amount of iron stored in the body) in these cyclists were abnormally high, a clear sign of intravenous iron and rHuEPO administration ${ }^{1,37}$.

In 1998, discovering rHuEPO ampoules with cyclists of a number of teams participating in the "Tour de France" was probably the most striking and publicized rHuEPO doping in recent sports events ${ }^{9,55}$. At the time, boxes with many ampoules of the drug were found in trucks of the main participating teams, and even in the competitors' lodgings, reflecting endemic use of this hormone among elite athletes $^{55-57}$. Over the 21 days of the competition, drug busts, inquiries and arrests were part of the competitions, which French newspapers called "Tour de Farce" $56,57$.

Some athletes, after health problems from the illicit use of rHuEPO, admitted having used this hormone. Such is the case of a cyclist who presented strong headache, nausea, vomiting, and photophobia two months before a competition, which lead to a diagnosis of idiopathic intracranial hypertension, non-responsive to standard treatment. Medical examination and lab tests suggested the use of rHuEPO, which was confirmed by the athlete upon questioning ${ }^{58}$.

In spite of all the cases above, liberation of the drug has been advocated by some groups, arguing that because rHuEPO is impossible to be detected, it is best to allow its use ${ }^{59}$. The IOC, however, included this recombinant hormone in the roll of forbidden drugs since $1990^{60}$, after Calgary Winter Games, where its use was evidenced, and the Seoul Olympic Games, both in 1988, even if such prohibition was just on a moral ground, due to lack of technology to fully detect and differentiate rHuEPO from endogenous $\mathrm{EPO}^{7,8,37,46,61-63}$.

\section{rHUEPO PREVENTION AND DETECTION METHODS}

\section{Indirect biologic markers}

For many years, one investigated how to overcome the problem posed by rHuEPO doping, due to impossibility of its detection and differentiation, as this is a structurally complex chemical, of high molecular mass, present in biologic fluids in low concentrations, and quite similar to its endogenous form ${ }^{7,8}$.

The possible solution to be adopted over the years to differentiate a high serum level of endogenous EPO from training in high altitudes or use of oxygen hypobaric cham- 
bers, until now allowed by IOC from illicit rHuEPO use, was to establish ranges of limits for normal standards closely related to the erythropoiesis process, making them markers of immediate or previous rHuEPO use $37,39,55,58,64$.

Thus, in 1997, the International Union of Cyclism (IUC) implemented random blood tests before each competition. The test involved measuring the level of hematocrit, and established that male athletes with a reading value of more than 50\%, and female athletes with hematocrit higher than $47 \%$ could not compete, on grounds that this would be a "hazardous competition" for them ${ }^{65}$. Indeed, the hematocrit is a physiological variable closely related to performance enhancement on exercise. An investigation carried out with the subcutaneous administration of rHuEPO has evidenced increase of hematocrit, of time of exhaustion from exercise, of maximum oxygen intake, and of systolic blood pressure $^{65}$. The side effects described for rHuEPO are more marked when excessive hormone doses raise hematocrit to values between 50 and $55 \%$, which typically occurs with endurance sports, due to natural dehydration ${ }^{45,46,54,59}$. Recently, IUC has adopted, as an additional criterion for allowing athletes to compete, the maximum level of serum hemoglobin of $17 \mathrm{~g} / \mathrm{dL}^{37,39}$.

IUC has always stated that the tests performed were health assessments, to prevent athletes from competing with "dangerously high" hematocrit; thus, a positive test result does not necessarily imply rHuEPO use, and athletes are suspended for two weeks only ${ }^{39,66}$. There were controversies on this limit, as dehydration status, the hour of the day sample is taken, and the body position of the athlete are limiting factors, in addition to the existence of a small proportion of elite athletes who present an hematocrit higher than the established limit without using rHuEPO $37,39,67$. This has been rebutted by the fact that hematocrit values from blood samples of athletes who competed before rHuEPO became available in the market were within the specified limits ${ }^{68}$. The International Federation of Ski has also implemented banning procedures for athletes, and adopted the limit of 18.5 $\mathrm{g} / \mathrm{dL}$ for serum hemoglobin. Excessively high limit values only redound in more doping cases ${ }^{37}$, fostering athletes to take rHuEPO until they reach hematocrit values close to the maximum allowed ${ }^{59}$ (which is possible with the extended use of low doses of hormone $)^{69}$. Portable cell counters and centrifuges were ever-present tools in sports arena, to ensure the established limits were not exceeded ${ }^{59}$.

Due to limitations in sample collection and problems related to the reliability in associating hematocrit values, a number of serum components were assessed as possible indirect markers of hormonal activity ${ }^{70}$. Reticulocytosis and macrocytosis are observed in the peripheral blood, reflecting an enhanced marrow activity, both after secretion of endogenous EPO and rHuEPO administration. Thus, both, reticulocytes and macrocytes have higher potential as parameters to indicate substance abuse, as their response in terms of serum concentration is quite proportional to the amount of serum rHuEPO ${ }^{2,71}$.

Other parameters considered as potential markers of rHuEPO use were concentration increase of soluble transferrin receptor (STR, a marker for erythroid activity) $72-75$ and increase in STR/serum ferritin ratio ${ }^{2,53,76}$. This ratio, however, cannot be used as a marker, alone, as additional iron supplement tends to balance this ratio by increasing ferritin levels $\mathrm{s}^{1,7,67,77,78}$. When iron supplement masks the STR/ferritin ratio, an increase in concentration of hypochromic erythrocytes is seen, and in this case they are the best markers when diagnosed immediately after rHuEPO administration $^{67}$.

When dosed in serum after administration of high rHuEPO doses, STR concentration increases, at the most, 5 times over basal level. However, it has been seen that the mRNA that presents this receptor increases in about 40 times. This information suggests that in a near future it will be possible to unfold observations towards the assessment of erythroid genetic markers to detect rHuEPO abusive use in sports ${ }^{7,15,77}$.

Due to the very low concentration of serum EPO, a study for an analytical possibility for detecting commercial rHuEPO forms was its immunological extraction with human antiEPO mono or polyclonal. A test performed in a variety of antibodies for different biologic species and manufacturers has shown that, in general, polyclonal antibodies were of high activity, but presented a high rate of cross reactions with proteins, whereas monoclonal antibodies have shown good specificity, but low activity. More encouraging results were found when magnetic pearls activated with immobilized antibodies were used as solid phase in immunomagnetic extractive procedures ${ }^{9}$. The use of anti-rHuEPO antibodies may also come to be applied to control animal doping, particularly horses, due to their crossed reactivity to equine $\mathrm{EPO}^{79,80}$.

Efforts to detect rHuEPO directly from the urine lead to parallel studies that sought physiologic markers of hormonal activity in this biologic fluid. Based in this fact, it has been suggested that rHuEPO use may act not only stimulating erythropoiesis, but also promoting a process of blood fibrinolysis and/or fibrinogenolysis. Such EPO catabolic action would be associated to urinary concentration values of fibrin and fibrinogen degradation by-products, which are blood proteins that take part in coagulation cascade. A screening performed in 76 world-class athletes who practiced sports with potential for rHuEPO has shown than more than $13 \%$ had high levels of these protein degradation by- 
products in the urine. As it was noted that physical wornout does not significantly promote this effect, it was concluded that athletes had used $\mathrm{rHuEPO}{ }^{8,75,81}$.

\section{rHuEPO detection in the Olympic Games}

In the end of the 90s, the IOC granted over US\$ 1.25 million for EPO research funds, in order for a test to be developed, that could screen the hormone in the Sydney Olympic Games of $2000^{39,55}$. In spite of the initial pessimism about meeting the deadlines, an international consortium established at the Australian Sports Drug Testing Laboratory developed, in time, an indirect method ${ }^{82,83}$ based on physiologic changes from the hematologic response due to hormone action ${ }^{55}$. This indirect test measured 5 blood parameters, one by one: erythrocyte, macrocyte and reticulocyte levels through the hematrocrit, and EPO and STR serum concentrations ${ }^{2,37,71,82-84}$. Even considering that rHuEPO was rapidly degraded, the method provided reliable results, even if the athlete discontinued administration two to three weeks before taking of blood sample ${ }^{71}$.

Pharmacokinetic and pharmacodynamic studies were performed in elite athletes, in order to define a "normal" physiological profile of specific endogen-dependant EPO variables, and also to find ranges of reference for the same blood variables after administration of the recombinant hormone ${ }^{2,39,70,74,78,84-92}$. Two mathematic models were designed with the use of data from placebo and rHuEPO: the ON model, to identify current rHuEPO users, and the OFF model, which was intended to identify the athlete who had recently discontinued rHuEPO administration ${ }^{2,82,93,94}$. After assessment of the different blood parameters in situations where one could get false positive and false negative results, from mathematic equations one defined the reference values for both models ( $\mathrm{ON}$ and $\mathrm{OFF})^{2,83,94}$.

At the same time, a direct test to detect rHuEPO was developed by Paris doping control lab, based on subtle differences between rHuEPO and physiologic EPO carbohydrate residues ${ }^{55,95}$. This test detects the presence of the synthetic hormone in the urine due to differences in the electric charges of each of the two forms under comparison, which allow for separation by means of isoelectric focalization electrophoretic technique ${ }^{3,30,59,95}$. Through this technique, after separation one can visually compare the progression of the bands (separate isoforms) of the hormone in the urine, through a $\mathrm{pH}$ strip. Disposition of the bands for rHuEPO alpha and beta forms (epoetina) are very similar (both present isoelectric point ranging from 4.42 to 5.11) even though epoetin beta presents extra basic bands. Both differ from natural purified EPO (with more acid bands, and isoelectric points ranging from 3.92 to 4.42 ). This test was assayed before the Sydney Olympic Games, in competi- tors of the 1998 Tour de France, and showed bands typical of the recombinant hormone in athletes one suspected of ${ }^{95}$.

The data collected at that time showed that urine test would detect the hormone up to three days after the last rHuEPO injection, which would allow for athletes to keep on using rHuEPO up to few days prior to the competition, thus participating of the event while under the effect of the hormone, with a negative test for rHuEPO. Thus, this test would be more suited to screening of athletes in the preseason and/or a complementary test for the Australian indirect test ${ }^{55,71,93,95}$.

Both, urine and blood tests for rHuEPO analysis were used at the Sydney Olympic Games 200094,96. However, to prevent the possibility of a false positive result, sanctions would only be taken with positive results for both tests ${ }^{71,93}$. At that time, Committee officials stated that athletes who refused to submit to the tests claiming ethical or moral reasons would de instantly excluded from the competition ${ }^{96}$. No positive case for rHuEPO was reported during the Olympics, even though there was some indication that a small number of athletes had apparently discontinued rHuEPO use few weeks prior to their arrival in Sydney ${ }^{93,94}$. Only 400 anti-rHuEPO tests were performed in Sydney, and, in relation to the total number of competitors, this low proportion favored the user athlete, as only 1 out of 20 athletes were sampled for rHuEPO, and "the idea of one having clean games was nothing other than an utopic fantasy"

Since then, rHuEPO analyses based on the described methods were performed in major international sports events, such as the 2002 Winter Games, in Salt Lake City. Over the competitions in this event, a total of 1,222 blood tests, and 72 blood and urine combined tests to detect rHuEPO were performed. In this event, 77 blood and urine combined tests were also made outside the competitions. No positive case for rHuEPO was found at the time. However, three positive cases have been described for another synthetic hormone, analogue to EPO, which has been recently released in the market, called darbepoetin alpha (Ara$\left.n e s p^{\circledR}\right)^{97,98}$. This hormone is biochemically different from rHuEPO forms for having two more carbohydrate chains bound to nitrogen atoms and for presenting amino acid replacements in 5 positions of the peptide skeleton. It also fosters production of red cells, being thus capable of enhancing performance of athletes, particularly in endurance sports $^{99-101}$.

\section{rHUEPO-RELATED FUTURE PERSPECTIVES}

IOC officials intend rHuEPO analysis to be further developed, as the direct method still takes a long time and is not too sensitive. Moreover, a higher number of accredited labs 
should be able to perform these analyses, but an important issue to be considerated for an usual rHuEPO analysis is the cost. An analysis including the necessary screening of forbidden drugs for doping control is of a somewhat high cost, and the inclusion of tests for rHuEPO will significantly add to the costs. Preliminary calculations have shown that the indirect test alone is responsible for an extra 25 dollars in the cost of each sample, not including the cost of blood sample taking ${ }^{71}$. Notwithstanding, some Brazilian sports federations already sponsor $\mathrm{rHuEPO}$ screening programs in some of their competitions, and recently a positive case was detected in a Brazilian athlete ${ }^{102,103}$.

Doping control lab will face important challenges in order to detect "endogenous-type" substances. New erythropoiesis-stimulating molecules generated from modified EPO are being developed by the pharmaceutical industry, to extend duration of effects and reduce frequency of administration, thus being very appealing to athletes who use this illicit resource ${ }^{96}$. One expects sensitive detection methods to be developed over the next few years, including electrophoresis in capillary zone ${ }^{104}$, and the combination of other chromatographic and spectrometric techniques ${ }^{3,105}$.

The future of blood tests seems to be connected to technological advancements in Medicine. It seems that nanotechnology will be, in the next few years, the road to be followed for drug analysis, both in therapeutics and in

\section{REFERENCES}

1. Adamson JW. Regulation of red blood cell production. Am J Med 1996; 101:S4-6

2. Ekblom BT. Erythropoietin. In: Bahrke MS, Yesalis CE, editors. Performance-enhancing substances in sport and exercise. USA: Human Kinetics, 2002:101-7.

3. Choi D, Kim M, Park J. Erythropoietin: physico and biochemical analysis. J Chromatogr B 1996;687:189-99.

4. IOC Medical Commission. IOC list of prohibited classes of substances and prohibited methods. 2003 Olympic Movement Antidoping Code, Appendix A, International Olympic Committee, Lausane.

5. River L, Saugy M. Peptides hormones abuse in sport: state of the art in the detection of growth hormone and erythropoietin. J Toxicol-Toxin Reviews. In press 2003.

6. Catlin DH, Hatton CK. Use and abuse of anabolic and other drugs for athletic enhancement. Adv Intern Med 1991;36:399-424.

7. Magnani M, Corsi D, Bianchi M, Paiardini M, Galluzi L, Parisi A, et al. Monitoring erythropoietin abuse in athletes. Br J Haematol 1999;106: 260-1.

8. Gareau R, Brisson GR, Chénard C, Gagon MG, Audran M. Total fibrin and fibrinogen degradation products in urine: a possible probe to detect illicit users of the physical-performance enhancer erythropoietin? Horm Res 1995;44:189-92.

9. Skibeli GA, Nissen-Lie GA, Noreau P, Torjesen P, Hemmersbach P, Birkeland KI. Immuno-affinity extraction of erythropoietin from human serum by magnetic beads. In: Schänzer W, Geyer H, Gotzmann A, MareckEngelke U, editors. Recent advances in doping analysis (6). Köln: Sport und Buch Strauß, 1998;313-29. sports, as it allows detection of different substances, from a drop of blood or other biologic fluid. One expects that, from then on, athletes do not object the performing of blood tests, and that lower detection limits may be achieved ${ }^{96}$.

It is likely, however, that in the 2008 Olympics a genetically modified athlete be a medal winner. Genetic therapy techniques are being used in medicine for experimental treatment of diseases, and unscrupulous athletes may come to use it. On an experimental basis, the EPO-codifying gen has been used in the treatment on anemias and renal diseases, as it produces an effectively endogenous form of hormone. However, as the medical use of DNA injections is not broadly disseminated due to difficulties in controlling the tissue of the application site, the use of this practice in sports is probably going to be delayed ${ }^{106}$.

\section{ACKNOWLEDGMENTS}

To Dr. Marília Rugani, from HEMORIO, for her critical review of this document; José Bonifácio University Foundation (FUJB), National Research Council of Brazil (CNPq), and Brazilian Soccer Federation for their support, and the Institute of Chemistry UFRJ for their unconditional support for doping-control research.

All the authors declared there is not any potential conflict of interests regarding this article.
10. Alberts B, Bray D, Lewis J, Raff M, Roberts K, Watson JD. Molecular biology of the cell. $3^{\text {rd }}$ ed. New York: Garland Publishing, 1994.

11. Rassier DE, Natali AJ, De Rose EH. Eritrocitemia induzida e dosagem sanguínea. Rev Bras Med Esporte 1995;1:11-5.

12. Oliveira MAB. Doping e coração. Rev SOCERJ 2000;13:53-60.

13. Constantinescu SN, Ghaffari S, Lodish HF. The erythropoietin receptor: structure activation and intracellular signal transduction. Trends Endocrinol Metab 1999;10:18-23.

14. Prchal JT, Semenza GL, Prchal J, Sokol L. Familial polycythemia. Science 1995;268:1831-2.

15. Dine G, Van Lierde, Rehn Y, Gillier N. Problèmes associés à l'usage de l'érythropoietin en milieu sportif. Immunoanal Biol Spéc 2001;16:23543.

16. Produtos Roche Químicos e Farmacêuticos S.A. Recormon ${ }^{\circledR}$ Eritropoetina beta: anemia em câncer. Rio de Janeiro: Roche.

17. Miyake T, Kung CKH, Goldwasser E. Purification of human erythropoietin. J Biol Chem 1977;252:5558-64.

18. Jacobs K, Shoemaker C, Rudersdorf R, Neill SD, Kaufman RJ, Mufson $\mathrm{A}$, et al. Isolation and characterization of genomic and cDNA clones of human erythropoietin. Nature 1985;313:806-10.

19. Rendic S. Human recombinant erythropoietin (rHuEPO) - physiology and biochemistry. In: Schänzer W, Geyer H, Gotzmann A, Mareck-Engelke U, editors. Recent advances in doping analysis (5). Köln: Sport und Buch Strauß, 1997;191-208.

20. Wide L, Bengtsson C. Molecular charge heterogeneity of human serum erythropoietin. Br J Haematol 1990;76:121-7. 
21. Birkeland K I, Hemmersbach P. The future of doping control in athletes - Issues related to blood sampling. Sports Med 1999;28:25-33.

22. Suassuna JHR. Via de administração da eritropoetina. J Bras Nefrol 2000; 22:29-31.

23. Gurney CW, Wackman N, Vilmanowitz E. Studies on erythropoiesis. XVII. Some quantitative aspects of the erythropoietic response to erythropoietin. Blood 1961;17:531-46.

24. Goldberg MA. Erythropoiesis, erytropoietin, and iron metabolism in selective surgery: preoperative strategies for avoiding allogeneic blood exposure. Am J Surg 1995;179:S37-43

25. Jansen JD, Madsen JK, Jansen LW. Comparison of dose requirement, serum erythropoietin, and blood pressure following intravenous and subcutaneous erythropoietin treatment in dialysis patients. Eur J Clin Pharmacol 1996;50:171-7.

26. Wendell RF, Waldman TA. The metabolism of erythropoietin in patients with anemia due to deficient erythropoiesis. J Clin Invest 1964;43:134854.

27. Jansen JD, Jansen LW, Madsen JK, Poulsen J. The metabolism of erythropoietin in liver cirrhosis patients compared with healthy volunteers. Eur J Haematol 1995;54:111-6.

28. Nielsen OJ, Jord ME, Hirth P. The metabolism of recombinant erythropoietin in the isolated perfused rat liver. Liver 1990;10:343-9.

29. Dunn J, Markham A. Epoietin beta, a review of its pharmacological properties and clinical use in the management of anemia with chronic renal failure. Drugs 1996;5:299-318.

30. Skibeli V, Nielsen-Lie G, Torjesen P. Sugar profiling proves that human serum erythropoietin differs from recombinant human erythropoietin. Blood 2001;98:3626-34.

31. Storring PL, Tiplady RJ, Gaines Das RE, Stenning BE, Lamikanra A, Rafferty B, et al. Epoetin alfa and beta differ in their erythropoietin isoform compositions and biological properties. Br J Haematol 1998;100: 79-89.

32. Helstenson CE, Macres M, Katz AS, Schnieders JR, Watanabe M, Sobota JT, et al. Comparative pharmacokinetics and pharmacodynamics of epoetin alfa and epoetin beta. Clin Pharmacol Ther 1991;50:702-12.

33. Uji Y, Hirashima K, Hirasawa Y, Iwasaki Y, Tohira Y, Mizuno K. A phase I study of recombinant human erythropoietin in healthy volunteers-multiple dosing study. New drugs physicians 1989;26:29-44.

34. Salmonson T, Danielson BG, Wikstrom B. The pharmacokinetics of recombinant human erythropoietin after intravenous and subcutaneous administration to healthy subjects. Br J Clin Pharmacol 1990;29:70913.

35. Flaharty KK, Caro J, Erslev A. Pharmacokinetics and erythropoietic response to human recombinant erythropoietin in healthy men. Clin Pharmacol Ther 1990;47:557-64.

36. Veys N, Vanholder R, Lameire N. Pain at the injection site of subcutaneous administered erythropoietin in maintance hemodialysis patients: a comparison of two brands of erythropoietin. Am J Nephrol 1992;12:6872.

37. Cazzola M. A global strategy for prevention and detection of blood doping with erythropoietin and related drugs. Haematologica 2002;85:5613.

38. Guezennec Ch-Y. Le dopage: efficacité, conséquences, prévention. Ann Endocrinol (Paris) 2001;62:33-41.

39. http://www.ausport.gov.au/ais/physiology/epoback.htm

40. Birkeland KI, Donike M, Ljungqvist A, Fagerhol M, Jansen J, Hammersbach P, et al. Blood sampling in doping control - First experiences from regular testing in athletics. Int J Sports Med 1997;18:8-12.

41. Ashenden M. A strategy to deter blood doping in sport. Haematologica 2002;87:225-34.

42. Simon TL. Induced erythrocythemia and athletic performance. Semin Hematol 1994;31:128-33.
43. Catlin DH, Murray TH. Performance-enhancing drugs, fair competition, and olympic sport. JAMA 1996;276:231-7.

44. Browne A, Lachance V, Pipe A. The ethics of blood testing as an element of doping control sport. Med Sci Sports Exerc 1999;31:497-501.

45. Scott WC. The abuse of erythropoietin to enhance athletic performance. JAMA 1990;264:1660.

46. Wadler GI. Drug use update. Sports Med 1994;78:439-55.

47. Adamson JW. Recombinant erythropoietin to improve athletic performance. N Engl J Med 1991;324:698-9.

48. Gauthier J. Effects cardiovasculaires du dopage. Ann Cardiol Angeiol (Paris) 2001;50293:8.

49. Aquino Neto FR. O papel do atleta na sociedade e o controle de dopagem no esporte. Rev Bras Med Esporte 2001;7:1-11.

50. Clyne N, Berglund B, Egberg N. Treatment with recombinant human erythropoietin induces a moderate rise in hematocrit and thrombin antithrombin in healthy subjects. Thromb Res 1995;79:125-9.

51. Casadevall N, Nataf J, Viron B, Kolta A, Kiladjian JJ, Martin-Dupont P. Pure red-cell aplasia and antierythropoietin antibodies in patients treated with recombinant erythropoietin. N Engl J Med 2002;346:469-75.

52. Cazzola M. Further concerns about the medical risks of blood doping. Haematologica 2002;87:232

53. Gareau R, Audran M, Baynes RD, Flowers CH, Duvallet A, Senécal L, et al. Erythropoietin abuse in athletes. Nature 1996;380:113.

54. Thein LA, Thein JM, Landry GL. Ergogenic aids. Phys Ther 1995;75: 426-39.

55. Zorpette G. All doped up - and going for the gold. Sci Am 2000;282: 20-2.

56. The Lancet (editorial). Peddling drugs to the pedal pushers. Lancet 1998; 352:415.

57. Jarvis CA. Tour de France. Br J Sport Med 1999;33:142-3.

58. Lage JMM, Panizo C, Masdeu J, Rocha E. Cyclist's doping associated with cerebral sinus thrombosis. Neurology 2002;58:665.

59. Jenkins P. Doping in sport. Lancet 2002;360:99-100.

60. http://www.wada-ama.org

61. Berglund B, Hemmingsson P, Birgegard G. Detection of autologous blood transfusions in cross-country skiers. Int J Sport Med 1987;8:66-70.

62. Casoni I, Ricci G, Ballarin E, Borsetto C, Grazzi G, Guglielmini C, et al. Hematological indices of erythropoietin administration in athletes. Int J Sport Med 1993;14:307-11.

63. Mottram DR. Banned drugs in sport - Does the International Olympic Committee (IOC) list need updating? Sports Med 1999;27:1-10.

64. Davey G, Nerurkar R. Doping in sport. Lancet 1998;352:1781-2.

65. Ekblom B, Berglund B. Effect of erythropoietin administration on maximal aerobic power. Scand J Med Sci Sports 1991;1:88-93.

66. Zorzoli M, Schattenberg L, Mangin P. The medical monitoring of the International Cycling Union. In: Schänzer W, Geyer H, Gotzmann A, Mareck-Engelke U, editors. Recent advances in doping analysis (8). Köln: Sport und Buch Strau $\beta, 2000 ; 83-7$.

67. Breymann C, Rohling R, Krafft A, Huch A, Huch R. "Blood doping" with recombinant erythropoietin ( $\mathrm{rHuEPO}$ ) and assessment of functional iron deficiency in healthy volunteers. Br J Haematol 2000;108:883-4.

68. Saris WHM, Senden JMG, Brouns F. What is a normal red-blood cell mass for professional cyclists? Lancet 1998;352:1758.

69. Russell G, Gore JC, Ashenden MJ, Parisotto R, Hahn AG. Effects of prolonged low doses of recombinant human erythropoietin during submaximal and maximal exercise. Eur J Appl Physiol 2002;86:442-9.

70. Souillard A, Audran M, Bressolle F, Gareau R, Duvallet A, Chanal JL. Pharmacokinetics and pharmacodynamics of recombinant human erythropoietin in athletes. Blood sampling and doping control. Br J Clin Pharmacol 1996;42:355-64.

71. Abbott A. What a price the Olympian ideal? Nature 2000;407:124-7. 
72. Dore F, Bonfigli S, Gaviano E, Pardini S, Longinotti M. Serum transferrin receptor levels in patients with talessemia intermedia during $\mathrm{rHuEPO}$ administration. Haematologica 1996;81:37-9.

73. Gareau R, Gagnon MG, Thellend C, Chénard C, Audran M, Chanal J-L, et al. Transferrin soluble receptor: a possible probe for detection of erythropoietin abuse by athletes. Horm Metab Res 1994;26:311-2.

74. Birkeland KI, Fiskum K, Bjerke B, Haug E, Hemmersbach P. Physiological and non-physiological variations in serum levels of soluble transferrin receptor - Implications for use as indicator of doping with $\mathrm{rHuE}$ PO. In: Schänzer W, Geyer H, Gotzmann A, Mareck-Engelke U, editors. Recent advances in doping analysis (7). Köln: Sport und Buch Strau $\beta$, 1999;289-90.

75. Brisson GR, Gareau R, Ayotte C. Induced haemostatic shift: a possible tool for EPO detection. In: Schänzer W, Geyer H, Gotzmann A, MareckEngelke U, editors. Recent advances in doping analysis (1). Köln: Sport und Buch Strauß, 1993;185-90.

76. Birkeland KI, Stray-Gundersen J, Hammersbach P, Hallen J, Haug E, Bahr R. Effect of rHuEPO administration on levels of sTfR and cycling performance. Med Sci Sports Exerc 2000;32:1238-43.

77. Magnani M, Corsi D, Bianchi M, Paiardini M, Galluzzi L, Gargiullo E, et al. Identification of blood erythroid markers useful in revealing erythropoitin abuse in athletes. Blood Cells Mol Dis 2001;27:559-71.

78. Robinson N, Marti B, Mangin P, Saugy M. Secondary markers of erythroid activity: any use for doping diagnosis in professional cyclists? In: Schänzer W, Geyer H, Gotzmann A, Mareck-Engelke U, editors. Recent advances in doping analysis (8). Köln: Sport und Buch Strau $\beta$, 2000; 79-82.

79. Bonnaire Y. Les problèmes actuels du controle antidopage équin. Revue Fr Lab 1999;310:73-6.

80. Kearns CF, Lenhart JA, McKeever KH. Cross-reactivity between human erythropoietin antibody and horse erythropoietin. Electrophoresis 2000;21:1454-7.

81. Gareau R, Brisson GR, Ayotte C, Dubé J, Caron C. Erythropoietin doping in athletes: possible detection through measurement of van Willebrand factor and D-dimer activity? Thromb Haemost 1992;68:481-2.

82. Parisotto R, Gore CJ, Emslie KR, Ashenden MJ, Brugnara C, Howe C, et al. A novel method utilizing markers of altered erythropoiesis for the detection of recombinant human erythropoietin abuse in athletes. Haematologica 2000;85:564-72.

83. Parisotto R, Wu M, Ashenden MJ, Emslie KR, Gore CJ, Howe C, et al. Detection of recombinant human erythropoietin abuse in athletes utilizing markers of altered erythropoisis. Haematologica 2001;86:128-37.

84. Audran M, Gareau R, Matechi S, Durand F, Chenard C, Sicart M-T, et al. Effects of erythropoietin administration in training athletes and possible indirect detection in doping control. Med Sci Sports Exerc 1999; 31:639-45

85. Yang SM, Wang XB, Fang ZL, Wang SH, Qin Y, Yi MQ, et al. Observation on hematology and biochemistry of six Chinese following rHuEPO administration. In: Schänzer W, Geyer H, Gotzmann A, Mareck-Engelke U, editors. Recent advances in doping analysis (5). Köln: Sport und Buch Strauß, 1997;215-21.

86. Breidbach A, Schänzer W. Individual reference ranges for serum erythropoietin (sEPO) - A possible approach to detect misuse. In: Schänzer W, Geyer H, Gotzmann A, Mareck-Engelke U, editors. Recent advances in doping analysis (6). Köln: Sport und Buch Strauß, 1998;301-10.

87. Hemmersbach P, Stray-Gundersen J, Hallén J, Haug E, Bahr R, Birkeland KI. The effects of suprafisiological doses of erythropoietin in healthy young men. In: Schänzer W, Geyer H, Gotzmann A, Mareck-Engelke U, editors. Recent advances in doping analysis (6). Köln: Sport und Buch Strau $\beta, 1998 ; 311-2$.
88. Bialas B, Breidbach A, Schänzer W. Individual reference ranges for serum erythropoietin (sEPO) - Part II: Influence of long distance flying. In: Schänzer W, Geyer H, Gotzmann A, Mareck-Engelke U, editors. Recent advances in doping analysis (7). Köln: Sport und Buch Strau $\beta, 1999 ; 301-9$.

89. Bialas B, Schwenke D, Schänzer W, Mülller RK. Diurnal variation of indirect parameters for the detection of recombinant human abuse in athletes. In: Schänzer W, Geyer H, Gotzmann A, Mareck-Engelke U, editors. Recent advances in doping analysis (9). Köln: Sport und Buch Strau $\beta, 2001 ; 311-6$.

90. Emslie KR, Howe C, Trout G. Measurement of urinary erythropoietin levels in athletes. In: Schänzer W, Geyer H, Gotzmann A, Mareck-Engelke U, editors. Recent advances in doping analysis (7). Köln: Sport und Buch Strau $\beta, 1999 ; 291-9$.

91. Birkeland KI, Hemmersbach P, Haug E. Blood sampling in doping control - Which new information may be obtained? In: Schänzer W, Geyer H, Gotzmann A, Mareck-Engelke U, editors. Recent advances in doping analysis (2). Köln: Sport und Buch Strauß, 1994;9-14.

92. Breibach A, Platen P, Schänzer W. Erythropoietin - Influence of strain and application on concentrations in blood and urine. In: Schänzer W, Geyer H, Gotzmann A, Mareck-Engelke U, editors. Recent advances in doping analysis (4). Köln: Sport und Buch Strauß, 1996;319-21.

93. Kazlauskas R. Sydney Olympics 2000: an overview. In: Schänzer W, Geyer H, Gotzmann A, Mareck-Engelke U, editors. Recent advances in doping analysis (9). Köln: Sport und Buch Strauß, 2001;167-77.

94. Trout GJ, Emslie KR, Howe C, Kazlauskas R, Lasne F. An overview of testing for EPO at the Sydney 2000 Olympic Games and beyond. In: Schänzer W, Geyer H, Gotzmann A, Mareck-Engelke U, editors. Recent advances in doping analysis (9). Köln: Sport und Buch Strau $\beta$, 2001; 191-200.

95. Lasne F, de Ceaurriz J. Recombinant erythropoietin in urine. Nature 2000; 405:635.

96. Birchard K. Past, present, and future of drug abuse at the Olympics. Lancet 2000;356:1008.

97. http://www.cafdis-antidoping.net/en/article.asp?articleid = 273\&page $=1$.

98. http://www.aranesp.com

99. Egrie JC, Browne JK. Development and characterization of novel erythropoiesis stimulating protein (NESP). Br J Cancer 2001;84:3-10.

100. Allon M, Kleinman K, Walczyk M, Kaupke C, Messer-Mann L, Olson $\mathrm{K}$, et al. Pharmacokinetics and pharmacodynamics of darbepoetin alfa and epoetin in patients undergoing dialysis. Clin Pharm Ther 2002;72: 546-55.

101. http://www.dshs-koeln.de/biochemie/rubriken/00_home/00_dar.html.

102. http://www.webrun.com.br/corridasderua/index.php?destinocomum $=$ noticia_mostra\&id_noticias $=635 \&$ id_eventos $=$.

103. http://www.cbat.org.br

104. Cifuentes A, Moreno-Arribas MV, Frutos M, Díez-Masa JC. Capillary isoelectric focusing of erythropoietin glycoforms and its comparison with flat-bed isoelectric focusing and capillary zone electrophoresis. J Chromatogr A 1999;830:453-63.

105. Stanley SMR, Poljak A. Matrix-assisted laser-desorption time of flight ionization and high-performance liquid chromatography-electrospray ionization mass spectral analysis of two glycosilated recombinant epoetins. J Chromatogr. In press 2003.

106. Adam D. Gene therapy may be up to speed for cheats at 2008 Olympics. Nature 2001;414:569-70. 